\title{
The Political Messages Embodied in Marvel’s Film Black Panther
}

\author{
ZHANG Juan \\ Beijing International Studies University, Beijing, China
}

\begin{abstract}
Black Panther is the first superhero film in Marvel's history that is directed and acted predominantly by African-American artists. The complementary academic review, high box office and audience rating are highly attributed to the political elements embodied in the movie. A breakthrough is achieved in the conventional cinematic image of the African-American man through the creation of a black hero playing the role of world savior. It also presents a prosperous and advanced image of Africa, fulfilling and expanding the African-American people's imagination of their spiritual home. Moreover, in responding to the Black Panther movement in black history, the film implicitly explores three possible routes of struggle for the black ethnic group and conveys a political message to the audience.
\end{abstract}

Keywords: Black Panther, superhero film, African-American politics

Black Panther, as the Marvel's 18th film product, quickly garnered exciting responses from film reviewers and the audiences after its release in January, 2018. The Atlantic's critic Christopher Orr comments that Black Panther is by far Marvel's most thought-provoking movie. Los Angeles Times writer Jen Yamato sees it as “A superhero movie about why representation \& identity matters, and how tragic it is when those things are denied to people” (Cavna, 2018). According to the data from Rotten Tomatoes, the most popular film review website in the United States, Black Panther's fresh rate reaches 97\%, and there are altogether 466 reviews, including 51 professional ones. Most reviewers agree that Black Panther has elevated superhero movies to a new height. Its box office has reached over 501 million dollars, which far surpasses any American film with a predominantly black cast. In contrast, the film is not that well received in the Chinese market. Both its box office and ratings are far below that of other superhero movies on show that year, such as Avengers 3, Aquaman, and Venom. The Chinese film critics are not that enthusiastic about the film either. The relatively poor performance of Black Panther in the Chinese market has a lot to do with its political codes that are out of the radar of the Chinese audiences in general.

The film contains rich political and cultural messages that concern the African-American experiences in the past several centuries. It no wonder triggers off complex emotions and memories among the African Americans and all those ethnic groups who share similar experiences. The film playwright and director Ryan Coogler indicates that Black Panther is a political character from the very inception, and that his story will remain true to the political elements. When the African-American Film Critics Association announced Black Panther as the best picture of 2018, its co-founder Shawn Edwards made a statement:

ZHANG Juan, Associate Professor, College of English, Beijing International Studies University, Beijing, China. 
Beyond its tremendous reviews and historic box office performance, the film changed the culture and became a defining moment for Black America. ... Many have waited a lifetime for a moment like this and Black Panther delivered with a multi-generational appeal never before seen. (Edwards, 2019)

It is therefore significant to take a closer look at the political momentum of this film in terms of its presentation of a new black hero, its imagination of the African root, and its political message for the African Americans today.

\section{A Black Hero}

Black Panther is one of very few movies in which an African-American superhero shoulders the responsibility of saving the world. It forms a sharp contrast with the long-standing black stereotypes in American literature and media. The ascribed attributes of blacks (and women) are succinctly summed up by the feminist theorist Kate Millett in Sexual Politics published in the 1970s, which include,

inferior intelligence, an instinctual or sensual gratification, an emotional nature both primitive and childlike, an imagined prowess in or affinity for sexuality, a contentment with their own lot which is in accord with a proof of its appropriateness, a wily habit of deceit and concealment of feeling. (2000, p. 57)

Such stereotypes have existed on screen ever since the invention of film at the beginning of the 20th century. In early mainstream films, black characters were either demonized or marginalized. Black male figures roughly fell into three categories: brawny and naïve Negro slaves in need of white guardianship, lazybones fooling around with no sense of duty, or brutal villains with uncontrollable libido. These images have been deeply embedded in American literary works and media products which continuously filter into the audience's minds and reinforce the already-existing stereotypes. They not only condition people's imagination of the black community, but also severely damage the African American’s self-esteem and self-identity.

After the civil rights movement in the 1960s, the screen image of the African Americans began to take a positive turn. Integrated, upright, and self-reliant male figures began to show up in mainstream movies, such as Guess Who's Coming to Dinner in 1967 and Driving Miss Daisy in 1989. More and more African American actors have starred in the mainstream movies since the 1990s and some actors have made their name, including Denzel Washington, Morgan Freeman, Will Smith, Samuel Jackson, and etc. Black screen images have become richer and more diversified, and to a certain degree have corrected the past stereotypes. And black characters are gradually moving from the margin to the center. Yet in the meanwhile, the vestiges of past decimation remain. Black actors often have limited choices among minor roles, antagonists, or clowns. Even if leading position is occasionally acted by an African American, the character gets a ticket into the mainstream society only after he wins appreciation of a gracious white employer or master.

In contrast, Black Panther presents a black hero who surpasses the past figures in every aspect, from his birthright and power to his humanity and charisma. The hero is no longer a grassroots nobody who has to go through all kinds of suffering in order to earn a place among the elites. The hero T'Challa is born a noble in a advanced kingdom of Wakanda. T'Challa has this high-tech armor made of arare metal named Vibranium, which can absorb any vibration and kinetic energy directed at it. Like a black panther, T'Challa has amazing speed, deftness, strength, and intuition. What's more, the heart-shaped herb could help the Black Panther to enter the underworld and have communion with his deceased father, thus gaining spiritual energy. More importantly, Black Panther is justice incarnate. The Caucasians, on the other hand, are portrayed as either evil 
or naive. Ulysses Klaue is a thief, greedy, and merciless. Ross is a CIA agent, but he ends up fighting under the command of Shuri, T'Challa's sister. In this movie, a black hero takes the place of the white guy and goes out to save the world. It is no doubt a great moment of mental empowerment for the African-American audiences.

Black Panther is like a new stray of light shed into the vast reservoir of the African-American collective memory. The conventional stereotype will not be overthrown once and for all. That is for sure. But it's like a thread of hope that inspires the African Americans to momentarily transcend the past traumatic experiences, and to imagine a stronger and confident self, thus having a broader spiritual horizon and an empowered inner world to face the reality.

Imagination shapes belief, and belief shapes action. The ways in which we are encouraged to imagine ourselves shape what we believe we can become. And, of course, what we believe shapes who we are. It does matter that a little black girl can now more easily imagine herself a princess. It is powerful that a young black man has the opportunity to see himself as a king or a superhero—not just as a villain or a criminal. (Emba, 2018)

What Christine Emba says above is very true. Each film portrait has political significance. When such images are more and more often seen on screen, the second-class identity of the African Americans will be about to collapse.

\section{An Imagined Africa}

Different from the real city scene in Marvel's other superhero movies, Black Panther is set in an imagined African country-Wakanda. Such a design is undoubtedly connected with the fact that Africa is the origin continent all African-American people have come or descended from. It in the meanwhile has more to do with the persistent pursuit of the African Americans for a cultural and spiritual home. Adam Serwer comments that,

Black Panther is a love letter to people of African descent all over the world. Its actors, its costume design, its music, and countless other facets of the film are drawn from all over the continent and its diaspora, in a science-fiction celebration of the imaginary country of Wakanda, a high-tech utopia that is a fictive manifestation of African potential unfettered by slavery and colonialism. (Serwer, 2018)

Since the Portuguese colonists stepped on the African continent in the16th century, exploitation and enslavement had been inflicted upon the inhabitants. Africa had been reduced to the source of raw materials and slave trade for the Western powers. Up to the early 20th century, 96\% of the African land had been occupied by the Western powers. Africa sunk into darkness and silence until it gained political independence in the 1960s and 1970s. But even after colonial rule ends, most African nations are still suffering from it legacy of poverty and warfare.

The film displays complex feelings of African Americans towards Africa. Africa is the spiritual root for the black Diaspora and at the same time a home they can never return. Ever since the Harlem Renaissance, black intellectuals, writers, and artists have set out on a journey of exploring and building their ethnic identity. They resort to studies on African culture as well as literary imagination for spiritual comfort and strength. The sense of ethnic pride was pushed to its peak during the civil rights movement when the doctrine of "Black is Beautiful” was put forward. The idea spread from the intellectuals to the ordinary blacks and Africa as the root of black culture and spirit has been widely accepted. African elements are also absorbed into almost every aspect of the black popular culture. Now decades have passed, but the root seeking journey continues, for the trauma of the black community still aches. The film director Coogler told an audience that "I have a lot of pain 
inside me. We were taught that we lost the things that made us African. We lost our culture, and now we have to make do with scraps" (Cobb, 2018).

So Coogler pieces together the scraps he has collected and put them into Wakanda, another piece built into the spiritual reservoir of the African Americans. The imagined Africa for a long time is a vast free land, primitive, mysterious, and beautiful. It's a legendary existence, free of the diseases and poverty that the real Africa is suffering today. Black Panther brings that imagination to a new level. Besides possessing all the above qualities, Wakanda enjoys the most advanced science and technology, propped by rich vibranium mine resources. It serves as symbol of a beautiful and prosperous African continent if it had never been colonized. Art is a tool with which the audiences manage to transcend the broken reality. Even for just a brief instant, a tiny piece of the collective wound could be cured.

But in the meanwhile, the dilemma African Americans face speaks loudly in the antagonist Killmonger. Africa is a home that he can never truly come back to. Even though Killmonger has the royal blood of Wakanda, he becomes an orphan after his father is killed in Oakland. He thus loses contact with his home country. Pain and alienation turn into rage and hatred, and those fill the void in his heart. He moves from one battlefield to another, killing people without mercy. He wants to kill T'Challa and rule Wakanda as Black Panther. His feelings towards Wakanda are complex. On one hand, he is overwhelmed with anger and hatred for all these years he has wandered and suffered as a deserted child. On the other hand, his inner heart is filled with deep yearnings to return home as his father tells him the sunset in Wakanda is the most beautiful scenery in the world. Many African Americans probably harbor the same kind of bittersweet emotions for Africa, particularly given the fact that living in the United States for many blacks is an experience of "double consciousness" in Du Bois' words. What Karen Attiah, the African-American writer and editor for The Washington Post, says is good proof:

In some twisted ways, I identified with Killmonger. Growing up, part of my exploration into where my parents came from, I felt a sort of anger towards Africa. Like, how did colonization happen to you? And the poverty? How are these leaders not doing more? And being black in America, when we are going through fights with racism, police brutality, we wonder if Africans even care. (Madowo \& Attiah, 2018)

\section{A Way Out}

The name of the film and hero, Black Panther, comes from Marvel's cartoon character Black Panther, which was created in July 1966. In October of the same year, the Black Panther Party for Self-Defense as a branch of the African-American civil rights movement was set up. It became known as Black Panther Party for short. Today Black Panther has become part of the American society as a period of collective memory and a cultural code. It symbolizes black strength, power, and identity. The movie therefore inevitably carries political implication and thoughts about the way out for the African Americans.

Coogler has created three Black Panthers in the movie, each representing a distinctive way of development for the Black community. T'Chaka, the old king, stands for isolationism and separation that help to safeguard the prosperity of Wakanda society amid colonial dominance. It in some way alludes to the avocation of black separation amid racial discrimination and suppression in American history. The black nationalists maintained that since black cannot possibly win equality and justice in a white-dominated world, they should separate with the whites and establish an independent nation of their own. Marcus Garvey was the most prominent black leader in this regard. He devoted great efforts to pan-Africanism and to build a nation for black Diasporas. He 
went so far as to contact the Ku Klux Klan and seek cooperation just because the party also upheld black and white separation. Garvey had been severely denounced by other black leaders such as W. E. B. Du bois, who believed that he was actually the greatest enemy of the blacks. Garvey's efforts aborted at last with the bankruptcy of his vessel company. Today as the U.S. power expands all over the world, isolationism is long excluded as an option. In the movie, T'Chaka is killed in a bomb explosion while he is making a speech in the United Nations, thus declaring the end of isolationism.

The second road is violent revolution, embodied by Killmonger. He has witnessed and experienced racial discrimination and suppression. He wants to take revenge upon the exploiters and colonists, launch a "tit for tat" fight against the whites, and build Wakanda into an empire. Killmonger is largely a symbol of the angry African Americans who have suffered agony and loneliness in a society they cannot assimilate into. The birth place of Killmonger in the movie is Oakland, the same place where the Black Panther Party was founded in 1966. The party's original purpose was to protect the African American community from white police brutality. They later developed into violent revolutionaries who called for the arming of all African Americans. The organization was eventually denounced and suppressed by FBI as the greatest threat to the national security. Even though the Black Panther Party believed that economic suppression was the root of racial deprivation and also provided survival programs and community help, it has got a name of militant revolutionary. Killmonger is like a Panther going rogue, holding a bigger ambition of overthrowing the white rule, and building a black empire. This way does not work out either in movie or in reality. The Panthers ceased their activities in the mid 1970s and 1980s. In the movie, Killmonger is to die. He says at the last moment: "Bury me in the ocean with my ancestors who jumped from the ships, because they knew death was better than bondage”. This is a poignant statement. No matter how much agony and hardships the blacks have suffered in the past, and no matter what kind of situation they are in today, revolution will get them nowhere in the current world.

Therefore, they have to take a third way. That is figured out and then adopted by T'Challa. He can no longer choose to hide his head in the sand and ignore the miserable conditions of the black people, and at the same time, he knows how dangerous revolution is for his people and the world. After hesitation and deliberation, he decides to connect with the outside world, to "build bridges”. T'Challa announces at the United Nations in Vienna that Wakanda will be sharing its knowledge and resources with the rest of the globe. "Wakanda will no longer watch from the shadows. We cannot. We must not", he says. For the African Americans, the message is clear, that the blacks should unite and help each other; they should work hard to improve their education and technological skills, so that they have a hope of achieving what they want. That is the message Coogler sends to the black audiences when the ordinary African Americans are left forgotten in the political environment of the United States today.

\section{Conclusion}

To sum up, Black Panther is no doubt a milestone in African American movie history. Its black superhero and the new imagination of Africa contribute to the efforts of rewriting the black memory and of rebuilding a collective identity. The movie also conveys a clear political message at the end after denying the two ways tried out in the past. Even though this seems like a cliché catering to the mainstream ideology, it serves as a dose of sobriety for the radicals. 


\section{References}

Cavna, M. (Jan. 30, 2018). "Black Panther” early buzz is hailing the film as a defining cinematic moment. The Washington Post. Cobb, J. (Feb. 18, 2018). "Black Panther” and the invention of "Africa”. The New Yorker.

Edwards, S. (Jan. 23, 2019). "Black Panther” named best film by African-American Film Critics Association. Hollywood Reporter. Retrieved from https://www.hollywoodreporter.com/news/aafca-names-black-panther-best-film-2018-1168424 Emba, C. (Feb. 16, 2018). "Black Panther” is a black triumph. America is afraid of those. The Washington Post.

Millett, K. (2000). Sexual politics, Illinois paperback. First published in 1970. New York: Doubleday.

Madowo, L., \& Attiah, K. (Feb. 16, 2018). Why the relationship between Africans and black Americans is so messed up. The Washington Post.

Serwer, A. (Feb. 21, 2018). The tragedy of Erik Killmonger. The Atlantic. 